\title{
A Revogação da Sentença no Direito Lusitano * (Perfil Histórico)
}

\author{
Moacyr Lobo da Costa \\ Professor Adjunto regente de História do \\ Processo Romano, Canônico e Lusitano \\ no Curso de Pós-Graduação da Faculdade \\ de Direito da Universidade de São Paulo.
}

\begin{abstract}
SUMARIO: 12.2 A ligão de Mello Freire - 12.3 A obra de Pereira e Sousa - 12.4 A exposicão de Pereira e Sousa - 12.5 As Segundas Linhas de Lobão - 13. Conseqüências da abolição da Revista de Justiça - 13.1 A Reforma Judiciária de 1832. O Recurso de Revista e wa acâo de nulidiode da sentenca - 13.2 A novissima reforma de 1841 . As modificacões quanto as Revistas e aça de nulidade - 13.3 Criticas ao novo sistema.
\end{abstract}

12.2 - Para implantar a reforma do ensino universitário, segundo os Estatutos de 1772, foram despachados para Coimbra alguns novos professores, entre os quais PASCHOAL JOSÉ DE MELLO FREIRE DOS REIS, que, na condição de lente substituto, inaugurou a cadeira de Direito Pátrio em 1774 e, tendo sido provido como catedrático em 1781, regeu-a até 1783 , quando foi chamado a Lisboa para o desempenho de outra incumbência de ordem legislativa. (cf PAULO MEREA, "Notas sobre alguns lentes de Direito Pátrio no Período 1772-1804", em Boletim da Faculdade de Direito, Coimbra, vol. XXXVI, p. 320).

Em cumprimento à determinação dos Estatutos, de que "o Professor será obrigado a formar um Compêndio Elementar da História do Direito Pátrio" (Estatutos, Liv. II, Tit. III cap. IX no 14), MELLO FREIRE escreveu logo sua "Historiae Juris Civilis Lusitani Liber Singularis", cujo manuscrito original em latim era lido em classe durante as lições, e que só veio à luz em 1788, impresso em Lisboa na Tipografia da Academia das Ciências, o mesmo acontecendo com as "Institutiones Juris Civilis Lusitani, cum Publici tum Privati", a obra máxima do grande jurista, cujos quatro tomos só foram impressos no ano seguinte na mesma Tipografia.

Identificado com o ideário iluminista, MELLO FREIRE, exerceu no campo das letras jurídicas um papel semelhante ao de VERNEY, tendo

* Continuação do Trabalho publicado no volume LXXVI. 
sido dos mais sérios o impacto causado por algumas das teorias expostas e defendidas nas "Institutiones", especialmente com respeito ao Direito Público, o que motivou mais tarde a inclusão do livro no "Index Librorum Prohibitorum", como informa INOCÊNCIO. (Diccionário Bibliographico cit. vol. XVII p. 146).

D'ele foi dito, com muita propriedade, ter sido o executor mais autorizado do espírito da Reforma Pombalina no terreno da jurisprudência teórica, e que foi, pode também dizer-se "o próprio VERNEY tornado jurisconsulto, ou a mais alta personificação ele mesmo do século XVIII nos domínios do direito". (CABRAL DE MONCADA, "O século XVIII na Legislação de Pombal", em Boletim da Faculdade de Direito, cit. p. 184).

Nas páginas das "Institutiones" encontra-se, em capítulos densos e concentrados, a exposição sistemática mais completa do Direito Lusitano, tanto público quanto privado, redigida em períodos simples e diretos, em estilo acentuadamente didático, com o emprego adequado dos termos e expressões jurídicas, que fez a fortuna dessa obra, tornando-a a mais lida e a mais procurada em suas sucessivas reedições, a que LOBÃO ajuntou suas "Notas a Mello", e da qual LOURENÇO TRIGO DE LOUREIRO extraiu, sem originalidade, suas "Instituições de Direito Civil Brasileiro" publicadas em Pernambuco, em 1851, depois de haver sido editada no mesmo Estado, entre os anos de 1834 e 1839, uma tradução dos quatro tomos das "Institutiones", realizada por partes por três tradutores diferentes, segundo informação de CLOVIS BEVILAQUA (História da Faculdade de Direito do Recife, ed. Liv. Francisco Alves 1927, vol. 2 p. 14 nota 12).

Por muitos e muitos anos o livro de MELLO FREIRE serviu, em Portugal e no Brasil, à formação profissional dos juristas, sendo raro o estudante, advogado ou juiz que o desconhecesse.

No tomo quarto, dedicado à explanação da matéria pertinente às obrigações e às ações ("De obligationibus et Actionibus") o Título XXIII, "De Appellationibus, supplicationibus, et revisionibus" trata nos parágrafos XXVI a XXIX da revisão das sentenças, que é definida como "remedium juris extraordinarium, quo causa a Principe iterum examinanda, et revidenda petitur, propterea quod judicatum nullitatis, vel manifestae injustitiae vitio loborat, a qual se chama, por um lado, de Justiça, e por outro de Graça Especial, ou Especialíssima.

Tendo em vista, contudo, a Lei de 3 de novembro de 1768, esclarece o mestre no $\S \mathrm{XXVII}$ : "Hodie nulla est revisio de justitia dicta, nec profecto illius expresso nomine mentionem faciunt antiquae, novaeque leges a nobis superius citatae". nova lei.

A Revista de Justiça não mais existe nem é mencionada na 
Toda Revista é agora de Graça Especial, pela nulidade ou injustiça notória da sentença, a ser requerida perante a Casa da Suplicação, ou então de Graça Especialíssima, pedida diretamente ao rei, nas causas em que a revisão é proibida, como nas criminais, ou quando tiver decorrido o prazo para ser impetrado o recurso.

Prosseguindo na lição, lembra o mestre que a Revista que se chamava de Justiça, tinha por fundamento a nulidade da sentença proveniente da falsidade das provas ou da corrupção do juiz; e, depois de explicar qual o fundamento das atuais Revistas de Graça, Especial e Especialíssima, acentua: "Differebant inter se: quia revisio de justitia ob dictas tantum duas nullitatis causas, et sine ulla quidem Palatti Curiae Senatorum informatione concedi solita erat, in eaque novae probationes, et allegationes admittebantur, quae non eodem prorsus modo ita se habent in revisione de gratia, vide Valasc Consult LI. Pereir. De Revision. Cap. VII".

Essa era, com efeito, a característica processual mais relevante da antiga Revista de Justiça, que a distinguia nitidamente da Revista de Graça, como sempre foi acentuado pelos praxistas e comentadores; o permitir a produção de novas provas e novas alegações de fora dos autos, que na Revista de Graça era vedado.

Porque a revisão é verdadeiramente um remédio extraordinário, ensina o mestre que não é de ser pedida subsistindo o ordinário, e mais ainda que não é de ser concedida contra sentença da qual se pode apelar ou suplicar.

No final do §XXVIII, examinando os dois casos exclusivos de revisão por Graça Especialíssima, é posto em destaque, corn ênfase, a proibição de se produzir algum documento de novo nos autos das Revistas, que antigamente o Príncipe costumava permitir, e que agora é expressamente proibido, e no caso de ser obtida dispensa, se julgue a mesma como obreptícia, sobreptícia e de nenhum efeito.

A lição de MELLO FREIRE desponta na literatura jurídica lusitana como, cronologicamente a primeira, e axiologicamente a mais autorizada interpretação do sentido da reforma introduzida pela Lei de 3 de novembro de 1768 . Lição que será seguida e invocada pelos juristas que vieram a escrever sobre o tema, como o foram sempre os ensinamentos de VALASCO, na memorável "Consultatio" citada por MELLO FREIRE cerca de duzentos anos depois.

12.3 - A exposição mais ordenada e completa do Recurso de Revista aparece no primeiro quartel do século XIX, no pequeno grande livro modestamente intitulado Primeiras Linhas sobre o Processo Civil, publicado em Lisboa, em 1810, impresso na Tipografia Lacerdina. Os muitos defeitos tipográficos dessa impressão levaram o autor a tirar nova edição, em quatro tomos, o primeiro impresso em 1813, na Oficina de Joaquim Rodrigues de Andrade, o segundo na Impressão Régia no mesmo ano, os terceiro e quarto na mesma Impressão Régia no ano de 1814, sem qualquer referência à edição anterior. 
Num gesto que pode ser interpretado como de repúdio à Edição Lacerdina de 1810, o autor reeditou em 1819, pela Tipografia Rollandiana, o primeiro tomo com a indicação no frontispício - "Segunda Edição" - tendo sido publicados os outros três tomos com a mesma indicação, em 1820, após sua morte. Igualmente, a nova publicação, pela mesma Tipografia Rollandiana, em 1825, é indicada como sendo "Terceira Edição".

Com isso a Edição Lacerdina caiu no olvido e seus exemplares tornaram-se verdadeiras raridades bibliográficas.

JOAQUIM JOSÉ CAETANO PEREIRA E SOUZA, seu autor, foi, durante muitos anos, advogado junto à Casa da Suplicação, como se declara na página de rosto do livro, o que lhe propiciou o conhecimento pessoal e direto do recurso extraordinário da revista, em razão do privilégio de impetrá-la, consoante a regra introduzida no Regimento dos Desembargadores do Paço, aprovado por D. SEBASTIÃO em 1564, e mantido nas Ordenações Filipinas, Liv. III, Tit. XCV, n 13.

Homem verdadeiramente culto mas de espírito prático, versado nas letras clássicas e jurídicas sem ser mero erudito, conhecedor profundo e experiente dos problemas do processo civil e criminal que se apresentavam e tinham de ser resolvidos no dia a dia do mais alto Tribunal do reino, cedo sentiu a falta que fazia, para advogados e magistrados, um livro que ordenasse de forma metódica e sistemática toda a doutrina do processo, compendiando os princípios dogmáticos e as regras da praxe, segundo as normas legais e os ensinamentos dos doutores, de modo a fornecer uma visão de conjunto do processo em sua integridade, mas de forma simples e sintética para ser entendido pelo leitor sem esforço de interpretação, como não acontecia com a generalidade dos livros de direito, em regra prolixos e desconexos.

Numa iniciativa pioneira em Portugal, entendera de distinguir o processo criminal do processo civil, muito embora não houvesse nas Ordenações separação entre os dois, que eram regidos pelas normas uniformes do Livro Terceiro, de aplicação indiscriminada a um e outro, salvo quanto às prescrições especiais atinentes à "Ordem do Juízo nos feitos crimes", do Título CXXIV, do Livro Quinto, em que, entretanto, a propósito de alguns atos e termos do processo é determinado "que se guarde o que Temos dito no Livro Terceiro", como se lê duas vezes no parágrafo 2 , e nos parágrafos 4 e 14; aliás, a determinação é reproduzida em outros Títulos, como por exemplo, no parágrafo 1 do Título CXXVI.

Coligiu ele, então, tudo que dissesse respeito ao processo criminal, textos legais, doutrina e jurisprudência, e, com base nesse farto material, elaborou uma exposição descritiva de todos os atos, termos, fases e incidentes, concatenados segundo a ordem em que procedem e se sucedem no desenvolvimento do processo no juizo criminal. 
Redígido com verdadeiro método didático e invulgar clareza, o trabalho foi publicado em 1785, sob o título de Primeiras Linhas sobre o Processo Criminal, obtendo grande sucesso que o levou a ser reeditado várias vezes em poucos anos.

Pela primeira vez, em Portugal, o processo criminal era objeto de tratamento autônomo, desvinculado do processo civil, e, particularmente do Direito Criminal, de que era considerado apêndice e como tal estudado pelos autores.

Até então as questões do processo criminal eram examinadas juntamente com as do processo civil, mas apenas pelo seu aspecto prático, nas conhecidas obras dos praxistas.

O primeiro praxista a dedicar um livro à prática do processo criminal, exclusivamente, foi MANUEL LOPES FERREIRA, que publicou em 1730-33, sua "Prática Criminal, expendida na forma da Praxe observada neste nosso Reino de Portugal", em 3 tomos, impressos na Oficina Ferreiriana, que saiu em $2^{\text {a }}$ edição, ampliada e melhorada, em 1741-42, em 3 tomos impressos na Oficina Carlos Esteves Mariz.

Que esta é a primeira obra de prática criminal, di-lo o próprio autor, nas palavras que dirigiu ao "Curioso Leytor": "tantos e tão grandes doutores se empregaram em compor vários Tratados e matérias da nossa jurisprudência, nenhum até o presente se empregou a fazer uma prática criminal. e ainda que a minha insuficiência não fosse capaz de emprego semelhante, com tudo me expuz a compor a que te ofereço", etc.

O livro está longe de poder ser considerado como um compêndio do processo criminal. Mesmo como livro de prática é mínimo seu merecimento.

Dele disse com ironia MELLO FREIRE, que devido ao seu tamanho mais peso do que auxílio prestava aos estudiosos do Direito Criminal, "ast magnitudine sua magis oneri, quam adjumento Juris Criminalis Studiosis esse videtur" ("Institutionum Juris Criminalis Lusitani, Liber Singularis", Prefácio).

No Demétrio Moderno, a apreciação do livro é que "não desempenha o prometido no título, por ser confusa, desordenada e sem sistema; todavia, não deixou de ser por muitos anos o ídolo dos nossos forenses". (ANTONIO BARNABÉ DE ELESCANO, Demétrio Moderno, ou o Bibliographo Jurídico Portuguez, Lisboa 1780, p. 170).

Um livro de prática para práticos, nos moldes do medíocre VANGUERVE CABRAL.

O livro de PEREIRA E SOUSA, pode ser considerado como o primeiro, porque a Prática de LOPES FERREIRA não cuida do processo como um todo, mas apenas do exame de questões controvertidas, limitando-se a apontar as soluções adequadas segundo a praxe. 
MELLO FREIRE, parco em elogios e pródigo em críticas, no Prefácio das Instituições de Direito Criminal, depois de se referir à Prática, acrescenta: à qual de preferência se recomenda, ao menos por sua brevidade e método, o pequeno livro intitulado Primeiras Linhas sobre o Processo Criminal, de 1785; "quibus potius ante omnia brevitate saltem sua et methodo commendandus parvus libellus inscriptus Primeiras Linhas sobre o Processo Criminal, aun. 1785"

Em 1794, nove anos após o aparecimento das Primeiras Linhas, MELLO FREIRE publicou suas "Institutionum Juris Criminalis Lusitani, Liber Singularis".

Um compêndo escrito com a finalidade de sistematizar o Direito Criminal do famigerado Livro Quinto das Ordenações, seguindo a. mesma orientação e com a mesma ordem e método das Instituições do Direito Civil.

Tal como o fizera com o processo civil, que reduzido à doutrina das ações é considerado como parte integrante do Direito Civil, cuja exposição sucede à das obrigações, no novo livro MELLO FREIRE engloba Direito Criminal e Juízo Criminal, discorrendo sobre ambos de maneira magistral, se bem que, já agora, inadequada para o processo criminal. Dos 23 Títulos, em que se divide o livro, os onze primeiros tratam dos diferentes crimes e os doze subseqüentes cuidam do Juízo criminal e dos correspondentes atos que nele se praticam.

Sem embargo de seu altíssimo merecimento, não se vislumbra nele a distinção entre direito e processo, nem a exposição deste é feita como de um ramo autônomo da ciência jurídica. A esse respeito é um livro tradicionalista, ao contrário das Primeiras Linhas, com sentido pioneiro e inovador.

Pelo Alvará de 16 de janeiro de 1805, foi incluída no $5^{\text {a }}$ ano do curso jurídico na Universidade uma cadeira de prática, não obstante o estudo do processo civil continuasse a ser feito na cadeira de Direito Civil, mediante o exame e interpretação dos textos do Livro Terceiro das Ordenações.

O processo era entendido como mero regulamento formal da ordem em que as causas eram tratadas em Juízo, e, para fins didáticos, como apêndice do Direito Civil.

O êxito alcançado pelo livro sobre o processo criminal e o conhecimento da premente necessidade de ser feito o mesmo com relação ao processo civil, devem ter estimulado PEREIRA E SOUSA a escrever as Primeiras Linhas sobre o Processo Civil nos mesmos moldes.

E plausivel admitir-se, também, que o autor tenha elaborado a obra com finalidade universitária, mesmo não sendo professor, tendo em vista a reforma introduzida pelo Alvará de 1805.

Por não ter escrito qualquer explicação preliminar, à guisa de Prefácio, Prólogo ou advertência ao leitor, como era usual, nada se 
sabe dos motivos determinantes de sua publicação, além do natural desejo do autor de contribuir com seu saber e sua experiência para o melhor conhecimento do assunto.

Nas edições corrigidas a partir de 1819 , o livro excede de muito o âmbito de simples compêndio, que o modesto título poderia sugerir.

$\mathrm{Na}$ verdade, é um tratado, não pela forma mas pelo conteúdo, por abranger a exposição ordenada e sistemática do processo civil em sua totalidade, sem omissão de qualquer de seus institutos. Um tratado elementar de Direito Processual Civil, o primeiro a merecer essa qualificação na literatura lusitana.

O valimento das Primeiras Linhas para o estudo do processo civil português, pela segurança dos conceitos, concisão e clareza jamais igualados por qualquer outro livro do gênero, perdurou mesmo após a promulgação do Código de Processo Civil de 1876.

Seus ensinamentos só foram ultrapassados quando o processo civil português se modernizou, assimilando as doutrinas da processualística italiana e alemã, por obra de JOSÉ ALBERTO DOS REIS, já no segundo quartel do século XX.

No Brasil, igualmente, as Primeiras Linhas tiveram larga penetração. Além das edições originais, que eram difundidas nos meios jurídicos, TEIXEIRA DE FREITAS preparou uma edição especial, acomodada ao foro do Brasil, até o ano de 1877, com avultado número de notas de sua autoria, atualizando-a segundo a legislação brasileira e os escritos de nossos juristas, cuja última publicação é de 1906.

O modelo de PEREIRA E SOUSA foi seguido por JOSE MARIA FREDERICO DE SOUSA PINTO, em suas Primeiras Linhas sobre o Processo Civil Brasileiro, publicadas em 1849, que TEIXEIRA DE FREITAS desconsiderou de maneira deprimente no Prólogo da sua edição.

No livro sobre o processo civil PEREIRA E SOUSA iterou o método adotado no anterior sobre o processo criminal, verdadeira inovação na literatura jurídica, que teve a melhor das acolhidas por parte dos leitores e conquistou a reputação de únicos no gênero para o estudo do processo: a separação física entre a parte expositiva e a fundamental. Em parágrafos curtos, redigidos com extrema concisão e clareza, são formuladas as definições e os conceitos teóricos, e nas notas de rodapé, abundantes e extensas, são indicados os dispositivos legais e os escritos dos autores, que lhes servem de fundamento, com o desenvolvimento do assunto versado no parágrafo.

12.4 - No Tomo segundo, dedicado aos recursos, o ultimo capítulo trata da Revista, nos parágrafos CCCLII a CCCLXXXII, encerrando a mais consumada exposição teórica desse recurso, depois da lição insuperável de VALASCO.

A Revista é definida como o recurso extraordinário que se interpõe das sentenças da maior alçada para o Príncipe. 
Divide-se em Revista de Graça Especial e Especialíssima. A primeira se impetra pelo Desembargo do Paço, guardada certa forma e debaixo de certos requisitos legais. A de Graça Especialíssima se impetra imediatamente do Príncipe e é sem limites.

A Revista, por via de regra é proibida, e somente se concede nos casos de nulidade manifesta ou injustiça notória. Por nulidade manifesta deve-se entender, segundo os Tit. 75 e Tit. 95, do Livro III: I. se faltou a primeira citação; II. se a sentença foi dada contra outra, passado em julgado; III. se foi dada por peita; IV se foi dada por falsa prova, não se havendo essa falsidade alegado nos autos, ou havendo-se alegado, mas não se havendo dado provas a esse respeito; V. se sendo muitos os Juízes não tiveram todos voto; VI. se foi dada por Juiz incompetente; VII. se foi dada contra direito expresso. Este direito expresso é o das Leis Pátrias do Reino, e não o das Leis Romanas ou outro direito subsidiário. É preciso porém que a sentença para ser objeto da Revista seja diretamente proferida contra as Leis, e não somente contra o direito da parte.

Não tem lugar a Revista: I. quando a causa cabe na alçada; II. a respeito das sentenças proferidas nos Tribunais Supremos; III. a respeito das sentenças proferidas em causas possessórias; IV nas criminais; V. quando ainda resta algum remédio ordinário; VI. nas causas de suspeição; VII. sendo a primeira vez denegada.

Quanto à regra da proibição em causas criminais, a nota 713 esclarece: exceto, I. quando com a pena criminal se julga a pena secundária, ou alguma outra civil, porque quanto a esta pode conceder-se Revista excedendo ela a taxa da Lei; II. por Graça Especialíssima.

Difere a Revista do Agravo Ordinário e da Apelação: I. em que ela é um remédio extraordinário; II. exige depósito; III. não suspende a execução da sentença; IV requer maior número de votos; $V$ é diverso o modo da sua expedição.

Os requisitos da Revista são: I, que se peça por escrito; II. que na petição se contenham as causas do gravame; III. que se interponha dentro de dez dias em competente audiência; IV que se apresente a petição de Revista no Tribunal respectivo dentro de dois meses; V. que seja assinada por Advogado da Casa de Suplicação; VI. que se caucione com certa soma de dinheiro; VII. que se lhe não ajuntem novos documentos, nem se façam novas provas.

Podem interpor a Revista: I. as partes que litigaram no processo; II. os herdeiros da parte agravada; III. os testamenteiros universais, não assim um terceiro.

Só pode conceder a Revista o Príncipe, o qual tem delegado esse poder ao Tribunal do desembargo do Paço. 
Não se revê o feito sem preceder Alvará, expedido pelo dito Tribunal e assinado pelo Real punho.

Somente podem ser revistas: I. as sentenças definitivas; II. as sentenças das Relações proferidas por Acórdãos, não as dos Tribunais Supremos.

O número dos Juizes da Revista deve sempre dobrar o daqueles que o foram na última instância. regras:

Quanto ao procedimento do recurso são traçadas as seguintes

Oferecida a petição no Tribunal respectivo e distribuída a um dos Ministros, o qual por seu despacho manda a parte responder dentro de quinze dias.

Feita a citação, com ou sem resposta da parte, tornam os autos ao Ministro, que dá o seu voto e os passa depois ao que lhe é imediato.

Se os dois Ministros discordam nos seus votos, o feito vai ao terceiro que desempata, concordando com um ou com o outro.

Concordando dois Ministros na denegação é logo escusado o requerimento. Se porém concordam na concessão, o Tribunal nomeia dois Desembargadores da Relação para informarem, e estes deliberam por tenções escritas se o caso é ou não de Revista. Se discordam nomeia o mesmo Tribunal um terceiro, que desempata.

Se os dois Desembargadores da Casa da Suplicação deliberam que o caso não é de Revista, ela se denega apesar dos dois votos permissivos dos Desembargadores do Paço. Se porém deliberam que é caso de Revista se manda passar Alvará para se rever o feito.

Na nota 744 o esclarecimento que o Alvará é assinado pelo Régio punho e se dirige ao Regedor da Justiça para fazer rever o feito, nomeando os Juízes para esse fim. O Alvará deve transitar pela Chancelaria - Mór do Reino, onde pode ser embargado, Ord. L. 1, Tít. 2 $\S 2^{\circ}$ e Tít. $30 \S 1^{\circ}$, L. 2 Tít. 39.

Em cumprimento ao Alvará o Regedor nomeia os Ministros para a revisão, sendo um como relator.

O relator manda dar vista às partes, primeiro ao recorrente e em seguida ao recorrido.

No caso de ser interposto agravo do relator, será julgado não pelos Desembargadores dos Agravos, mas pelos Juizes nomeados para a revisão,

Com as alegações das partes o feito é concluso ao relator, que o examina e passa para o outro Juiz segundo a ordem da nomeação, e assim para os demais, pondo cada um o sinal de ter visto os autos. Em seguida assina-se dia para o julgamento. 
Nesse dia o relator expõe o assunto em Relação, na presença de todos os Juízes nomeados, e se escreve a sentença segundo o voto da maioria, devendo assiná-la todos os Juízes, ainda os que deram voto contrário.

A respeito dos efeitos da sentença, a regra é fazer-se logo na mesma sentença da Revista a condenação do recorrente no perdimento da caução, quando a revisão é julgada improcedente e confirmada a sentença recorrida, ou mandar-se restituí-la quando a sentença recorrida é revogada.

A sentença da Revista admite Embargos na Chancelaria e segundos Embargos no caso de restituição, de acordo com o estatuido no Alvará de 6 de dezembro de 1813, que revogou um antigo assento da Casa da Suplicação em sentido oposto.

A Revista não suspende a execução das sentenças, nem produz litispendência, senão depois que a causa é cometida aos Desembargadores da Relação para se rever o feito e a parte é citada para arrazoar.

Não se provê na Revista senão o recorrente.

A condenação dos frutos feita na sentença da Revista não se estende aos frutos percebidos durante a causa da mesma Revista.

O vencedor na Revista recobra a importância da Dizima ou da parte vencida, se a Fazenda Real já a tiver embolsado, ou do Recebedor se a parte vencida não tiver bens.

A última norma exposta por PEREIRA E SOUSA, no final da dissertação, tem muito mais a natureza de preceito de direito público constitucional, como prerrogativa de quem vive como súdito de um soberano, embora na época de pleno absolutismo ainda não se cogitasse de direito constitucional em Portugal, do que, verdadeiramente de uma norma de processo. Reza o § CCLXXXII:

A Revista de Graça Especialíssima, bem como qualquer outra queixa imediata ao Príncipe, é um recurso que sempre está patente, e livre a todo o Vassalo.

E na correspondente nota 758 , desenvolve o tema com as seguintes considerações:

Esta Revista não está sujeita a norma alguma particular, e pende em tudo do Real arbítrio. Regularmente o Príncipe, nestes recursos extraordinários e imediatos, manda informar algum Ministro com audiência da parte. Umas vezes decide o Príncipe o caso por si mesmo, e a decisão baixa por Decreto ou aviso expedido pela mesma Secretaria de Estado: outras vezes nomeia Juízes que decidam, outras vezes finalmente manda consultar o Tribunal competente; e no caso de se conformar com a consulta, sendo esta a favor do recorrente, 
pelo mesmo Tribunal se expede Provisão em que se declara, que a Ordem é de especial resolução Régia.

Com essa explicação do mecanismo da Revista de Graça Especialíssima, o eminente processualista, dos maiores que Portugal conheceu em todos os tempos, encerra o capítulo que trata da Revista.

Não obstante as modificações introduzidas pelas leis posteriores, alterando significativamente a natureza do recurso de Revista e particularmente o seu processo, o discurso de PEREIRA E SOUSA perdurou na doutrina como um corpo de princípios teóricos, que foram invocados pelos processualistas ao examinarem o recurso à luz da nova legislação.

12.5 - Em 1817 apareceram em Lisboa, impressos pela Impressão Régia, os dois tomos da obra intitulada "Segundas Linhas sobre o Processo Civil, ou antes Adições às Primeiras, do Bacharel Joaquim José Caetano Pereira e Sousa", de autoria de MANOEL DE ALMEIDA E SOUSA, o conhecido advogado de Lobão.

É flagrante a diversidade entre as Primeiras e as Segundas Linhas, a revelar a diferença entre um jurista culto e um advogado referto de erudição.

Enquanto naquelas o processualista se esmerou por apresentar uma exposição sistemática do processo civil em sua totalidade, descrevendo os institutos com rigorosa precisão, numa linguagem simples de invulgar clareza, com raras porém oportunas citações de autoridades, o que torna o livro de agradável e fácil leitura, nestas dá-se exatamente o contrário, pela falta de método e de sistema, servindo, algumas vezes, não para completar e esclarecer o sentido das Notas de PEREIRA E SOUSA, como se propôs, mas para torná-las confusas em razão de sua maneira desordenada de argumentar, de citar autores, com e sem propósito, e particularmente de seu estilo, ou falta de estilo.

Se é certo que lendo apenas as Primeiras Linhas qualquer estudante chegaria a ter um conhecimento preciso e seguro do processo civil, é duvidoso que lendo tão somente as Segundas pudesse chegar ao mesmo resultado.

Ainda que escrito para atender aos reclamos dos principiantes, como declarado no Prefácio, na verdade o livro do "letrado d'Aldêa" só foi útil aos advogados. O tom polêmico da exposição é de advogado a discutir questões e sustentar pontos de vista, e não do jurista dissertando sobre temas de direito processual.

As inúmeras dúvidas e controvérsias suscitadas ao longo desses dois volumes, acompanhadas das soluções preconizadas pelo homem de Lobão, serviram muito mais para abastecer o arsenal dos militantes, para as disputas do fôro, do que contribuíram para o entendimento doutrinário do Direito Processual Civil em Portugal, como as Primeiras Linhas. 
Ao tratar da Revista, no tomo segundo, ALMEIDA E SOUSA pôs de lado as observações que vinha fazendo às Notas das Primeiras Linhas, para encetar, de maneira desordenada e prolixa, uma série de comentários aos dispositivos da Lei de 3 de novembro de 1768.

Malgrado a forma desconexa, o mérito desses comentários, a par de sua condição de únicos sobre o assunto, reside no equacionamento de alguns problemas, como por exemplo o seguinte: - o $\S 3^{\circ}$ da Lei determina que, por direito expresso, para se apurar se a sentença é notoriamente injusta, por ter sido proferida contra ele, deve-se entender "o Direito Pátrio dos meus Reinos, e não as Leis Imperiaes, ou Direito Civil"; ora, observa o comentarista, depois dessa Lei, o mesmo legislador D. JOSÉ esclareceu não só na Lei de 18 de agosto de 1769, como nos Estatutos da Universidade, que o Direito Romano devia ser observado e aplicado como subsidário das Leis Pátrias, quando estas fossem omissas, estando pois em colisão com o disposto na Lei de 1768. Se, por omissão das Leis Pátrias, o caso for julgado contra alguma Lei Romana, clara, justa e qualificada tal na forma dos Estatutos, será fundamento para se suplicar Revista contra a sentença, como proferida contra direito expresso?

Tendo formulado a questão, o comentarista lembra que, se atendemos à última legislação, ou como derrogatória ou como declaratória da Lei antecedente, a Revista deverá ser concedida, porque é o mesmo proferir-se a sentença contra Lei Pátria, que contra Lei Romana autorizada como subsidiária no caso de omissão. Se, porém, considerarmos odiosas as Revistas, a Lei de 1768, especial, ainda que anterior, é de ser considerada uma limitação das leis gerais posteriores, e a Revista não deve ser concedida. Acrescenta, então, que esta última interpretação é privativa dos Senhores Desembargadores do Paço, "bem que cá de longe e do cantinho da minha Aldeia tenho observado, que as Revistas se concedem, quando nos casos omissos nas Leis Pátrias, as Sentenças de que se pedem, são notoriamente injustas, e proferidas contra as Leis Romanas, qualificadas justas, e recebidas nesses Artigos pelo uso das Nações, ou Legislações destas, etc." (Segundas Linhas, Lisboa 1817, Parte II. p. 147, 148).

$\dot{E}$ curioso que, depois de ter advertido logo no começo de sua dissertação que "Devemos prescindir do quanto sobre a índole das nossas Revistas discorrerão Pereira de Revision, Silva à Ord. L. 3 T. 95, com os mais Reinícolas, à face do que nos declarão a Lei de 3 novembro de 1768 e alvará de 6 de janeiro de 1813", nos subseqüentes comentários à mesma Lei, a autoridade de PEREIRA, em seu clássico "De Revisionibus", continue sendo citada, seguidamente, por LOBÃO.

Como quer que seja, a leitura desses comentários é necessária para uma visão da problemática gerada pela Lei de 3 de novembro de 1768. 
13 - A mais séria conseqüência da abolição da Revista de Justiça, pela Lei de 3 de novembro de 1768 , foi a de que a sentença proferida com fundamento em falsa prova, testemunhal ou documental, ou que fosse fruto do suborno do Juiz, só poderia ser revogada pela via ordinária, "per viam nullitatis", pois não podia mais ser objeto de revisão.

A concorrência dos dois remédios, previstos nas Ordenações e que fora oportunamente ressaltada por VALASCO, desapareceu só subsisíndo o meio ordinário, que, em substância, era a antiga "querela nullitatis" do direito intermédio, herdada da Lei das Sete Partidas, como resultou demonstrado em trabalho anterior (A Revogação da Sentença na Península Ibérica, S.P. 1979, p. 91 etc,).

A Revista de Justiça, que se propunha perante o Desembargo do Paço, era processada em autos apartados, comportando libelo, contestação, réplica e tréplica, produção de provas e alegações de fato e de direito, tendo a natureza de recurso sob a forma de ação ordinária com a finalidade de promover a revisão da sentença impugnada, e, para a "querela nullitatis", destinada a anular a sentença em idêntica situação e pelos mesmos motivos, o processo adotado pela praxe era formalmente o mesmo da Revista de Justiça, embora sem previsão legal específica.

Não se encontrando nas Ordenações, nem os autores fornecendo qualquer indicação no sentido de qual dos dois remédios o interessado deveria escolher, e em que hipóteses, é admissível que a reforma Pombalina tenha tido por objetivo acabar com essa situação de perplexidade, apontada por VALASCO, a par da manifesta determinação de reduzir a revisão das sentenças à condição de remédio extraordinário depen. dente da Graça do Rei.

13.1 - O sistema criado pela Lei de 1768, entretanto, esteve em vigor até o advento da Reforma Judiciária, de 1832, promovida por D. PEDRO, Duque de Bragança, pelo Decreto $n^{\circ} 24$ de 16 de Maio de 1832.

Muitas foram as modificações que a legislação revolucionária, promulgada sob a responsabilidade direta e pessoal do Ministro da Justiça de D. PEDRO, introduziu no arcaico regime estabelecido e vigente para a divisão e funcionamento dos organismos incumbidos de distribuir justiça.

Visando desemperrar e agilizar a máquina judiciária, o grande estadista liberal MOUZINHO DA SILVEIRA promoveu uma profunda reforma, reorganizando e redistribuindo os órgãos e autoridades judiciárias de primeira instância, por círculos judiciais, comarcas, julgados e freguesias, e os de segunda instância em Tribunais, criando o Supremo Tribunal de Justiça, com sede em Lisboa, como órgão de cúpula com atribuições específicas, entre as quais a de conhecer e julgar o recurso de revista, nos casos estabelecidos nas leis. 
Consoante o disposto no artigo 243, do Decreto $n^{2} 24$, de 16 de maio de 1832, que instituiu a Reforma Judiciária, proferida a sentença no Tribunal de segunda instância, as partes interessadas, e o Procurador Régio nos casos permitidos em lei, poderão interpor o recurso de revista para o Supremo Tribunal de Justiça, devendo guardar-se, na interposição e apresentação, os mesmos termos e prazos estabelecidos para a apelação. No artigo 244 é remetida para o regimento do Tribunal a determinação dos casos em que o mesmo toma conhecimento do feito, para conceder ou negar a revista, in verbis: "Os casos, em que o Supremo Tribunal de Justiça toma conhecimento do feito, para conceder ou negar a revista, serão determinados no regimento do mesmo Tribunal."

Todavia, antecipando-se ao regimento, o legislador baixou, três dias depois, o Decreto de 19 de maio, destinado a fixar definitivamente as atribuições e ordem do serviço do Supremo Tribunal de Justiça criado pelo Decreto de 16 do mesmo mês, como se declara no respectivo preâmbulo.

O capítulo I, do referido Decreto, trata da competência do Tribunal, e seu artigo $1^{\circ}$ dispõe: Compete ao Supremo Tribunal de Justiça:

Primeiro.

Segundo. .

Terceiro: "Conhecer, ou negar Revistas nas causas Cíveis, e Criminais, declarando nullos os processos, em que houver nullidade constante dos próprios autos, não tendo sido objeto de discussão nos juizos competentes".

$\S 1$ : : "Há nullidade todas as vezes que se commetter contravenção directa às Leis do Reino em vigor, ou seja, primeiro: preterindo-se alguma das formalidades, que ellas estabelecerem, sob pena de nullidade; ou segundo: não se conformando na applicação das mesmas com a sua litteral disposição".

Inspirada no ideário do liberalismo, a reforma aboliu as figuras da Revista de Graça Especial e de Graça Especialíssima, criações do absolutismo monárquico que tinham mais a natureza de benefícios a serem concedidos pela munificência do Príncipe, do que de recursos jurídicos colocados à disposição dos litigantes.

Em seu lugar foi estruturado, como meio de impugnação da sentença eivada de nulidade, um recurso próprio dirigido ao Tribunal competente, sem qualquer dependência do poder real.

A Revista nos casos crimes deixou de ser um favor, de Graça Especialíssima, para tornar-se um recurso jurídico como nos casos cíveis. 
Para afastar o arbítrio na caracterização da nulidade, o diploma legal conceituou-a como contravenção direta às Leis do Reino, em vigor, seja pela preterição de alguma das formalidades estabelecidas sob pena de nulidade, seja pela aplicação das mesmas em desconformidade com sua literal disposição.

O artigo $2^{\circ}$ dispõe que só pode interpor-se o Recurso de Revista, primeiro: das sentenças definitivas proferidas em Segunda Instância; segundo: das sentenças proferidas pelos Juízes árbitros, nos casos em que as partes são obrigadas por Lei a recorrer a eles.

$\mathrm{O}$ artigo $3^{\circ}$ estabelece que os processos cíveis serão decididos pela Seção Civil do Tribunal e os processos crimes pela Seção Criminal.

No artigo $4^{\circ}$ e seus parágrafos são estabelecidas algumas importantes regras atinentes ao processo e julgamento das Revistas.

Art. 4" "A decisão de cada uma das Secções sobre os Processos, que lhe forem submetidos, não poderá ser embargada, nem della haverá recurso algum, ou as ditas Secções concedam, ou neguem a Revista pedida".

$\S 1$ "No caso de concessão não poderá qualquer das ditas Secções reter o Processo, e decidir a questão principal; mas deverá este ser remettido ao Tribunal, ou Juízo designado pela mesma Secção segundo as disposições seguintes":

\section{Quanto aos Processos Cíveis:}

$\S 2$ "Se a nulidade provier de se ter omittido alguma solemnidade substancial do Processo até á Sentença de primeira Instancia, o dito Processo será declarado nullo, e remettido a outro Juizo de primeira Instancia differente do primeiro, para se proceder a nova instrucção, novos debates, e nova decisão; mas se a nullidade occorrer depois da Sentença da primeira Instancia, será declarada nulla aquella parte sómente do Processo, que fôr posterior á nullidade; e sustentando-se a decisão da primeira Instancia, o Processo baixará a outro Juízo de primeira, ou segunda Instancia, segundo a nullidade tiver ocorrido n'um, ou n'outro; porém sempre differentes do primeiro, para se reparar a referida nullidade, e seguirem-se d'ahi os termos ulteriores".

$\S 3$ " $S e$ a nullidade vier da falta de conformidade com a disposição litteral da Lei, declarada nulla a decisão de direito, baixará o Processo a outro Juizo de primeira, ou segunda Instancia, segundo a nullidade tiver ocorrido n'um, ou n'outro, mas sempre differentes do primeiro, a fim de se dar execução á Lei".

Quanto aos Processos Crimes:

$\S 4^{\circ}$ Quando a nulidade provier de se ter preterido alguma solemnidade substancial do Processo antes da ratificação da pronuncia, o Processo será annullado em todo, e remettido a outro Juizo de ins- 
trucção, para ahi sel preparado legalmente, e seguir os termos ulteriores perante o Juiz de Direito de primeira Instancia, e o Tribunal de segunda Instancia superiores ao referido Juizo de instrucção. Se a nullidade acontecer depois da ratificapção da pronuncia até á decisão do Juizo de primeira Instancia, será declarada nulla essa parte do Processo sómente, e será este remettido a outro Juizo de primeira Instancia differente do primeiro, para ser novamente processado".

$\S 5^{\circ}$ "Quando a nulidade ocorrer depois da Sentença de primeira Instancia, ou quando provier da falta de conformidade com o texto da Lei, se observará o que fica disposto na segunda parte do $\S 2^{\circ}$ e no $\S 3^{\circ}$.

$\S 6^{\circ}$ "Segunda Revista sobre o mesmo caso nunca será concedida".

A regra estabelecida no parágrafo segundo é tipicamente do processo romano da "restitutio in integrum": declarada a nulidade pelo Supremo Tribunal (iudicium rescindens), o processo era remetido a outro Juizo ou Tribunal, diferente daquele que proferiu a decisão rescindida, para se proceder a nova instrução e julgamento do feito (iudicium rescissorium).

O sistema de atribuir ao Supremo Tribunal a competência para conceder ou negar Revistas nas causas e pela maneira que a lei determinar, e de atribuir aos Tribunais de segunda instância a competência para o julgamento do mérito desses recursos, uma vez concedida a Revista, não constitui originalidade da reforma judiciária portuguesa, mas é simples reprodução do sistema introduzido no Brasil pela Carta Constitucional do Império, outorgada por D. PEDRO em 25 de março de 1824 , artigo $164,1^{\circ}$, e pela Lei de 18 de setembro de 1828 , que criou o Supremo Tribunal de Justiça e declarou suas atribuições. (cf. Moacyr Lobo da Costa, Breve notícia histórica do Direito Processual Civil Brasileiro e de sua Literatura, São Paulo 1970, p. 2 a 4).

É verdade que o sistema havia sido esboçado na Constituição portuguesa de 23 de setembro de 1822 (art. 191 e 192) de efêmera vigência, o qual não chegou a funcionar pois o Supremo Tribunal de Justiça só foi efetivamente criado pelo Decreto $n^{\circ} 24$, de 16 de maio de 1832 .

Como os diplomas legais brasileiros e portugueses provinham da autoridade em que se encontrava investida a mesma pessoa, o príncipe D. PEDRO, é irrefutável que ele trasladou para o reino, que regia em nome de sua filha, o sistema que havia introduzido anos antes no império por ele mesmo fundado.

Invertendo os papéis, agora era a antiga colônia que exportava para a ex-metrópole fórmulas e princípios jurídicos !

No artigo $5^{\circ}$ do Decreto de 19 de maio, encontra-se uma disposição de profundo significado e ampla repercussão: "A acção de nullidade ficará competindo somente nos casos em que se verificar suborno, 
peita, peculato, ou concussão nos Juizes, ou nos Jurados, se estes não tiverem sido criminalmente julgados antes de proferida Sentença na última Instância; porque nesse caso se usará do Recurso de Revista".

O texto revela a permanência da antiga "querela nullitatis", sob a forma de ação de nulidade, nos casos de suborno, peita etc. de Juízes, ou Jurados, quando estes não tiverem sido criminalmente julgados antes de ser proferida sentença na última instância, ao lado do Recurso de Revista a ser interposto, quando aqueles motivos de nulidade da sentença tiverem de ser julgados depois do Tribunal de última instância ter proferido sua decisão no feito.

Contra a nulidade da sentença decorrente do suborno do Juiz, ou Jurados, a reforma de 1832 restabeleceu os dois remédios concorrentes, a ação de nulidade e o Recurso de Revista, mas estabeleceu como critério discriminativo para o cabimento de um ou do outro, ter ou não havido decisão definitiva do Tribunal de última instância.

Dir-se-ia haver o legislador optado pela primitiva solução aventada para o problema por VALASCO, mas por ele próprio reformulada, por parecer-lhe inadequada. (cf. VALASCI, Consultatio LI, octavus quesitum, ver supra $n^{\circ} 4$, p. 58).

A despeito do critério discriminativo prescrito na lei, não seria despicienda a advertência feita por VALASCO a seu consulente: "Haec in proposito memoro, ut tu interim meliora cogites".

13.2 - No afã de aprimorar a organização judiciária e facilitar o andamento dos processos para melhor realização da Justiça, segundo os dictames do liberalismo que então inspirava a atividade do Governo, foi decretada em 21 de maio de 1841 uma nova reforma judicial, que se tornou conhecida como a "novissima".

Era a terceira, a partir de 1832.

Com respeito ao Recurso de Revista è mantido o sistema introduzido pela reforma de 1832, com a competéncia do Supremo Tribunal de Justiça para conceder ou negar a Revista nos casos e pelo modo estabelecido nas leis, e, concedida ela, designar o juízo ou tribunal em que há de ser novamente julgado o feito (Novis. Ref. Jud. art. 20, 1%).

As Relações julgarão em segunda e última instância pelo modo estabelecido no Decreto, as Revistas concedidas pela Supremo Tribunal (art. $42,2^{\circ}$ ).

O Supremo Tribunal, dividido em duas secções, conhece e julga os Recursos de Revista em feitos cíveis, crimes e da fazenda nacional (arts. 793, § $2^{\circ}$ e 796, §único).

Vencendo-se a concessão da Revista por haver nulidade e contravenção às leis do reino, preterindo-se alguma das formalidades substanciais ou daquelas que as leis estabelecem sob pena de nulidade, ou não se conformando a aplicação das leis com a sua literal dispo- 
sição, terá lugar a designação do juízo aonde o efeito deve ser remetido, para no caso de faltar alguma daquelas solenidades se instaurar de novo o processo, ou aquela parte que for declarada nula, e se seguirem os termos ulteriores, e no caso de falta de conformidade com a lei, se lhe dar execução e se seguirem os referidos termos. (art. 815)

O juízo a que o feito for remetido será sempre diverso do primeiro e da primeira ou segunda instância, segundo numa ou n'outra tiver ocorrido a nulidade ou a violação da lei. (parágrafo único do art. 815)

Quanto ao cabimento do Recurso de Revista, dispõe o artigo 682 que o mesmo compete das sentenças definitivas, e interlocutórias com força de definitivas, proferidas em segunda instância em causas, cujo valor exceda a alçada estabelecida no $\S$ único do art. 45 , e em todos os casos especialmente declarados neste Decreto.

A seguir, nos $\S \S 1^{\circ}, 2^{\circ}$ e $3^{\circ}$ do art. 682 , estão estabelecidas algumas normas sobre o procedimento a ser adotado na Revista, a mais significativa das quais sendo a que determina dever observar-se tudo o mais que foi decretado para interposição e apresentação das apelações, o que, a nosso ver, importou na ampliação da regra do art. 243, do Decreto $n^{\circ} 24$, de 1832, que mandara observarem-se apenas os mesmos termos e prazos prescritos para a apelação. $\mathrm{Na}$ expressão "tudo o mais" estaria compreendido o respectivo procedimento.

A Revista, que no sistema das Ordenações e da Reforma Pombalina tinha a natureza de um recurso extraordinário, dependente da Graça Especial, ou Especialíssima, do Soberano, torna-se um recurso ordinário e de justiça, cuja concessão compete ao Supremo Tribunal de Justiça. (cf. F J. Duarte Nazareth, Elementos do Processo Civil, $3^{\text {a }}$ ed. Coimbra 1860, § 560 nota $a$, p. 384 ).

Trata-se, sem dúvida, de uma das mais importantes e autênticas conquistas liberais, originárias da reforma realizada pelo príncipe regente D. Pedro, em 1832, que a "novissima" manteve e aperfeiçoou.

Com a finalidade de disciplinar a competência do Supremo Tribunal, de acordo com as normas da "novíssima" reforma, foi votada cm Cortes Gerais a Lei de 19 de dezembro de 1843.

O novo diploma legal começa por estabelecer distinção entre nulidade do processo e nulidade da sentença, in verbis: art. 1. "O Supremo Tribunal de Justiça conhece, em recurso de revista, de nullidade do processo e de nullidade de sentença" $\quad$ - $\$ 1^{\circ}$ " $\hat{E}$ nullo o processo, em que houver preterição de algum acto essencial, ou de fórmula. para elle estabelecida por lei com pena de nullidade." $\quad-\$ 2^{\circ}$ " $\hat{\mathrm{E}}$ nulla a sentença que julgar directamente o contrário do que dispõe qualquer lei do reino, ou della fizer applicação manifestamente errada, ou que tiver algum defeito substancial, ou de que resulte nullidade na conformidade da Ordenação livro 3 , título 75 , e mais leis do reino" 
A esse respeito lembra CORREA TELLES que, de acordo com a Ordenação do Título 75 , do Livro 3 , "a sentença é ipso jure nulla, e nunca passa em julgado, $1^{\circ}$, se foi proferida contra direito expresso em uma Lei do Reino; $2^{\circ}$, se foi dada por Juiz incompetente, cuja jurisdição era improrrogáável; $3^{\circ}$, se é contra outra sentença já dada entre as mesmas partes, e sobre o mesmo objeto; $4^{\circ}$ se foi dada por peita ou preço, que o Juiz recebeu; $5^{\circ}$, se foi dada por prova falsa; 6 ${ }^{\circ}$, se os Arbitros erão dous ou mais, e uns julgárão sem os outros; $7^{\circ}$ se a parte não foi citada no princípio da causa, ou se a citação foi falsa". (J. H. CORREA TELLES, Manual do Processo Cívil, $3^{\circ}$ ed. Coimbra 1849, § 274, p. 108).

A nulidade da sentença por qualquer dos motivos enumerados serve de fundamento para a interposição do Recurso de Revista.

A propósito do julgamento da nulidade do processo, dispõe o artigo $2^{\circ}$ da nova lei, que o Supremo Tribunal julga definitivamente sobre termos e formalidades do processo; e no caso de o declarar nulo, manda proceder à sua reforma no mesmo ou em em diverso juízo, segundo julgar conveniente.

Quanto à nulidade da sentença, a regra estabelecida no artigo $3^{\circ}$ é que o Supremo julga a nulidade e manda julgar de novo a causa, ou pela mesma Relação, se nela houver número duplicado de juizes para que a causa possa ser julgada por diversos dos que o foram da sentença anulada, e assim o entender conveniente, ou por outra Relação. Quando a sentença anulada tiver sido proferida em primeira instância, será a causa remetida a diverso juízo.

Por sua relevância, as nulidades do processo e da sentença podem ser conhecidas pelo Supremo Tribunal, ainda que não apontadas na minuta do recurso, e mesmo na falta desta, segundo o disposto no artigo $6^{\circ}$.

De par com várias regras sobre o processo e julgamento da Revista, a nova lei previu a possibilidade de segunda Revista contra o julgamento proferido nas Relações (art. 5\%), admitiu embargos de declaração nas Revistas das causas criminais (art. 13) bem como nas de quaisquer causas cíveis, nas quais serão admitidos, também, embargos infrigentes, quando se tenha julgado com falsa causa sobre nulidade do processo (art. 14\%).

Uma das modificações de maior significação e alcance no campo do direito processual foi a ampliação dos casos de cabimento da ação de nulidade, criada pelo Decreto de 19 de maio de 1832, que era restrita às hipóteses de suborno, peita, peculato ou concussão de juízes ou jurados.

Dispõe o art. $17^{\circ}$ da nova lei:

"A acção de nullidade e rescisão da sentença terá logar, além dos casos especificados no artigo quinto do Decreto de dezenove de Maio 
de mil oitocentos trinta e dois: primó - quando se tiver julgado por um ou mais documentos, que depois se provar serem falsos, e cuja falsidade não tenha sido allegada na causa, em que se tiver proferido a sentença rescindenda: secundo - quando sobrevier um ou mais documentos novos que destruam a prova, que serviu para o julgamento anterior, sem que sejam coadjuvados por prova testemunhal, e que a parte interessada não pudesse ter ao tempo em que se proferiu a sentença rescindenda: tertio - quando a parte condemnada, sem ter comparecido em juizo, provar falta ou nullidade de citação nas causas, cujas sentenças se executam sem dependencia de prévia citação do executado, não competindo porem esta acção, e só o meio prescripto no artigo 617 da Novíssima Reforma Judicial, se tiver havido citação para a execução: quarto - quando o executado provar falta ou nullidade de citação para a execução finda à sua revelia, a fím de se annullar a mesma execução"

Observa-se um aprimoramento terminológico na lei, que chama a ação "de nullidade e rescisão da sentença", e a esta de "rescindenda". Era como que o certificado do bastimo legal da ação rescisória no Direito português, a qual vai sobreviver no Código de Processo Civil de 1876 e desaparecer no novo Código de 1939.

O problema da nulidade da sentença proferida com base em documentos que se alega serem falsos, ou em documentos que sobrevieram após a sentença ter passado em julgado e que destruam a. prova acolhida por ela, é um problema tormentoso que sempre ocupor a atenção dos processualistas.

Em tais hipóteses o remédio indicado era o pedido de restituição, sempre que concorressem os requisitos de terem sido os documentos descobertos após o trânsito em julgado da sentença, de serem verdadeiramente desconhecidos da parte que os alega, e de serem de tal relevância que a sentença não teria sido prolatada naquele sentido se a parte os tivesse em mãos antes, como escreveu SYLVA, em seus Comentários (ad. Ord. Lib. 3 tit. 87, ad principium $\mathrm{n}^{\circ} 23$ ).

Escrevendo antes da lei de 19 de dezembro de 1843, LOBÃO, sustentou, nas Segundas Linhas (Parte I, nota $471 \mathrm{n}^{\circ}$ 6) que depois de passar em julgado a sentença, ela é impugnável, ou na execução (e suspensivamente, ex SYLVA $\left.n^{\circ} 24\right)$, ou depois de executada, por ação ordinária, quando ao vencido apareceram documentos convincentes, que haviam sido subtraídos ou ocultos pelo adversário vencedor.

Não obstante haver escrito que a sentença, depois de executada, é impugnável por ação ordinária, no desenvolvimento do tema LOBÃO demonstrou que o meio para a retratação da sentença, no caso, era o remédio extraordinário da restitutio in integrum (op. cit. loc. cit. $\mathrm{n}^{\text {os }} 8$ e 9 )

O outro meio, apontado por Lobão, para se desfazer a sentença transitada em julgado, mas ainda não executada, eram os Embargos 
de novo supervenientes, que se apresentavam na execução, e em que se alegava a descoberta de documentos novos ou a falsidade dos documentos em que se fundamentou a sentença, (Tractado Encyclopédico, Prático, Crítico, sobre as Execuções que procedem por Sentenças, Lisboa 1817, $\S 215$ e 218).

13.3 - Com o advento da Lei de 19 de dezembro de 1843, os dois meios para se obter a revogação da sentença eivada de nulidade e conseqüente rescisão do julgado, o Recurso de Revista e a ação de nulidade, ficaram diferenciados e bem delimitados os respectivos campos para o cabimento e aplicação de cada um.

O Recurso de Revista cabe das sentenças definitivas, e das interlocutórias com força de definitivas, proferidas em segunda instância, nas causas de valor superior a seiscentos mil réis, quando houver preterição de algum ato essencial, ou de fórmula para ele estabelecida por lei com pena de nulidade, ou quando a sentença tiver julgado diretamente o contrário do que dispõe qualquer lei do reino, ou dela fizer aplicação manifestamente errada, ou tiver algum defeito substancià̃, ou de que resulte nulidade na conformidade da Ordenação Livro 3, Título 75, e mais leis do reino.

Nas causas de valor inferior a seiscentos mil réis, bem como naquelas de valor superior, mas em que não houve recurso para a segunda instância, era incabível o Recurso, de Revista, mesmo verificando-se qualquer dos motivos de nulidade do processo ou da sentença.

A ação de nulidade e rescisão da sentença tem lugar nos restritos casos previstos no art. $5^{\circ}$, do Decreto de 19 de maio de 18.32, e no art. 17, da Lei de 19 de dezembro de 1843, ou seja, nos casos de suborno, peita, peculato ou concussão de Juízes ou Jurados; de falsidade documental; de descoberta de novos documentos; de falta ou nulidade de citação, nas causas julgadas à revelia; de falta ou nulidade da citação para a execução processada à revelia do executado.

Para evitar abusos na utilização desta ação, o § único do art. 17, da Lei de 1843, estabeleceu a condenação no dobro das custas e da multa, que não poderá exceder a um conto de réis, para quem intentar a ação e dela decair.

Tal sistema, entretanto, foi recebido com reservas e mereceu algumas ponderadas críticas.

Um dos primeiros a se manifestar foi um conhecido advogado de Lisboa, DR. MENDONÇA, que demonstrou, com hábil argumentação, que as disposições do Decreto de 19 de maio de 1832 e da Lei de 19 de dezembro de 1843, não podem ter aplicação às causas em que pela sua menor importância não cabe o recurso de apelação nem o de revista, porque não pode ser imputada culpa ao vencido, por não ter usado daqueles recursos, nem há razão para lhe negar o 
remédio da Ord. Liv. 3 Tit. 75. (MENDONÇA, Memória, em Gazeta dos Tribunais, $1843, \mathrm{n}^{\circ} 315$ )

CORREA TELLES, referindo-se ao art. 17, da Lei de 19 de dezembro de 1843, escreve: "Com esta disposição não se remedea o mal que tinha causado o art. 5' do Decr. de 19 d'Agosto de 1832 (sic. é de maio); e em meu entender melhor fôra revoga-lo e suscitar a observância da Or. L. 3. T. 75. Vej. a sábia Memória do Sr. Mendonça na Gazeta dos Trib. de 1843 n. 315". (Mannual do Processo Civil, cit. Addicções ao § 274, p. 297)

Menos radical é a opinião de DUARTE NAZARETH. Depois de lembrar que a sentença nula não transita em julgado e não produz efeitos, de acordo com o princípio expresso na Ord. Liv. 3 Tit. 75, observa que, tendo o Decreto de 19 de maio de 1832 e Lei de 19 de dezembro de 1843, restringido e tornado taxativos os casos de nulidade e rescisão de sentença, segue-se que a sentença de que não há recurso, embcra seja ilegal, não pode invalidar-se, quando se não verifiquem alguns dos casos, em que é permitida a ação de nulidade e rescisão; conseqüientemente pode haver sentença nula, e todavia passar em julgado.

Reportando-se à tese do Sr. MENDONÇA, cuja doutrina foi perfilhada por CORREA TELLES que escreveu: "de se não adoptar esta doutrina, pelo decurso dos anos havemos de ver sentença de juízes incompetentes, ou dadas contra a expressa determinação das leis, ou contra a prova dos autos, valerem como moeda de boa lei"; assinala NAZARETH que esta doutrina, porém, não é tida por muito segura, jorque a disposição daquelas leis é geral e extensiva a todas as sentenças. " $E$ porem certo", conclui o ilustre catedrático de Coimbra, "que a legislação vigente neste assumpto é defficiente e carece de reforma, pois ha casos de egual e ainda maior consideração do que os apontados nella, em que deve conceder-se a acção de nullidade". (Elementos, cit. p. 346 , nota $a$ )

O sistema implantado com as Reformas Judiciárias e leis posteriores, a despeito das críticas, esteve em vigor até a promulgação do Código de Processo Civil, em 1876, o qual, todavia, manteve, em suas linhas gerais, as duas figuras da ação de nulidade e rescisão de sentença e do Recurso de Revista, como meios de impugnação das sentenças eivadas de nulidade, com pequenas alterações que não as descaracterizaram.

Como agudamente observou o prof. PAULO MEREA, foi sob a inspiração da lei francesa sobre o recurso de cassação e função do Tribunal de Cassação, que o legislador português orientou a reforma judiciária, substituindo o antigo Desembargo do Paço pelo Supremo Tribunal de Justiça, que foi criado, como se declarou no Decreto de 8 de novembro de 1833, "para guarda e defesa das leis, para fiscalizar a sua verdadeira inteligência e fiel execução, e para evitar caprichosas e várias interpretações das mesmas leis". Essa é a função específica da Cour de Cassation, segundo o disposto na Lei de 27 de Novembro de 1790, 
cujo art. $3^{\circ}$ reza que a Cour de Cassation "annulera toutes procédures dans lesquelles les formes auront été violées et tout jugement qui contiendra une contravention expresse au texte de la loi".

A partir dessa data pode, pois, dizer-se, afirma PAULO MEREA, que"a revista mudou de carácter, pois, não só perdeu por completo o carácter de graça, mas passou a ter como função predominante e específica defender a lei contra a inobservância dos seus preceitos por parte do poder judicial" (cf. PAULO MEREA, "Bosquejo histórico do recurso de revista", in Boletim do Ministério da Justiça, $\mathrm{n}^{\circ}$ 14, p. 66).

A doutrina de que a finalidade do Recurso de Revista é a defesa da lei e, portanto, só deverá ser admitido com base na violação ou inobservância dos seus preceitos, transitou para o Código de Processo Civil de 1876. (Continua no próximo volume). 